\title{
Persuasive and Humanist Da'wa Message on the Gus Mus' @s.kakung Instagram Account during the COVID-19 Pandemic
}

\author{
Asna Istya Marwantika ${ }^{1^{*}}$ \\ ${ }^{1}$ Institut Agama Islam Negeri Ponorogo, \\ Ponorogo - Indonesia
}

Article Information

Submitted February 14, 2021

Revised April 03, 2021

Accepted April 23, 2021

Published May 30, 2021

\begin{abstract}
The COVID-19 pandemic in Indonesia requires contributions from Islamic leaders to educate and provide information to the public. As an Islamic leader, Gus Mus actively responds to this condition through his Instagram account @s.kakung. This study determines Gus Mus's contribution to the da'wa message uploaded by @s.kakung, from the preaching theme and the strategy of delivering da'wa's message. This research uses a qualitative descriptive method with qualitative content analysis techniques_data collected from the @s.kakung Instagram account from March 16, 2020 - March 29, 2021. The results showed that the da'wa message uploaded by the @s.kakung in faith, Sharia, and moral. The creed announces that we must never forget Allah, obey Allah's commands in pandemic conditions. Da'wa messages on the Sharia theme, such as making inner efforts, are praying, wirid, sholawat, and Hizib autad practice. The moral theme messages support the movement to help people affected by COVID-19 comply with health protocols by wearing masks, keeping their distance, washing hands, and avoiding crowds. Meanwhile, the strategy of delivering Gus Mus' da'wa messages in the @s.kakung Instagram uses more persuasive and humanist.
\end{abstract}

Keywords: Da'wa messages, Gus Mus, Instagram, COVID-19 pandemic

\section{Introduction}

The COVID-19 pandemic that has attack Indonesia since March 2020 requires careful handling to reduce the crisis in society. Crisis communication during a pandemic covers the essential health fields, such as socialization of adhering to health protocols and how to pray during the pandemic to the socialization of vaccinations.

Stakeholders, such as a government, community or religious organizations, social media influencers (Alam, 2020; Sofian, 2020), and Islamic public figures (Arrobi \& Nadzifah,
2020; Aula, 2020; Hidayaturrahman et al., 2021; Munir et al., 2020; Pabbajah et al., 2020) have contributed to wrap up Covid-19 pandemics. Religious figures have three roles: a) motivate to reduce confusion, b) deliver trusted pandemic information, and c) role models that the community follows (Aula, 2020).

Islamic public figures contributed to the COVID-19 pandemic communication both institutionally and individually. Digital media has recorded the new-normal era from the early pandemic to the vaccination

*Author Correspondence: Asna Istya Marwantika, email:marwantika@iainponorogo.ac.id, address: Jl. Pramuka No. 156 PO.Box 116 Ponorogo, East Java, Postal Code 63492

Copyright (C) 2021 Asna Istya Marwantika 
socialization period. Digital media, especially websites and social media, are essential pillars for disseminating information during a pandemic. The social media user penetration increased by 10 million or around $6.3 \%$ of Indonesia's 170 million population during the pandemic. Indonesians' favorite social media applications are YouTube, WhatsApp, Instagram, Facebook, and Twitter, with an average usage of three hours and 14 minutes / day. (Kompas.com, 2021).

Social media also amplifies da'wa messages during the pandemic. It has characteristics, such as a) connection between users, b) up-to-date information, c) live interaction, d) durable archiving, e) social simulations, f) user-generated content, and g) massive content sharing (Fakhruroji, 2017; Nasrullah, 2016).

The da'wa messages distribution on social media during the pandemic consists of three periods: a) the initial period of the pandemic, b) the new-normal period, and c) the vaccination period. From March to May 2020, the Indonesian Ulama Council (MUI) disseminate a fatwa in the early pandemic period. There are four MUI fatwas, namely a) performing worship rituals in a pandemic, b) praying guidelines for medical personnel, d) covering the Covid-19 Muslim corpse, and e) Eid praying guideline (Suherdiana et al., 2020).

Besides the MUI's fatwa, Nahdlatul Ulama (N.U.) urges Nahdliyin to do Qunut Nazilah regularly. It takes precautions by obeying health protocols in worship and educational institutions, temporarily not doing religious activities. It Involves many masses, managing the N.U. Cares for COVID-19 Task Force and maximizing fundraising and distributing aid through LAZISNU. Meanwhile,
Muhammadiyah also issued worship guidance during the COVID-19 pandemic, religious diversion through online media, and publishing da'wa through the Muhammadiyah website and social media.

Apart from religious authorities, individual Islamic leaders also spread da'wa messages in the early pandemic via YouTube (Briandana et al., 2020). For example, Habib Novel Alaydrus delivers da'wa messages on YouTube so that people follow the direction of the government and give guidance to Muslims to guard their hearts, always leaning on Allah SWT. Ustadz Adi Hidayat suggests Muslims take physical and spiritual endeavors. Ustadz Abdul Somad, through his YouTube channel, urged Muslims to follow MUI fatwas and read more istighfar, prayers, be patient, increase alms, and repent to Allah SWT (Munir et al., 2020). In addition, Gus Mus revealed that the COVID-19 pandemic is a phenomenon that places restrictions on worship rituals. It includes congregational prayers in mosques, recitation, and Friday prayers to do at home to reduce Covid-19 outspread temporarily. Rukhsah makes maslahat for Muslims. Gus Miftah emphasized that Muslims should not be worried and afraid but not underestimate COVID-19. Be vigilant and apply health protocols recommended by the government, and always present the Messenger of Allah in every dhikr istighfar, shalawat so that Allah will guard against punishment and calamity. Gus Baha explained that the effort to comply with health protocols is not because of fear of COVID-19. If exposed to COVID-19 will be troublesome for others, and the quality and quantity of worship Allah will decrease (Hakim \& Aziz, 2020).

Da'wa messages in the new-normal began with the publication of the guidelines 
socialization for religious activities in worship places, as stated in the circular letter issued by the Minister of Religion 15/2020 (Kompas.com, 2020). Worship and religious activities are gradually being allowed because the area is not classified as a red zone and always adheres to health protocols. However, during this new standard period, hundreds of scholars were exposed to COVID-19, and hundreds of them died (Tribunnews, 2021). K.H. Said Aqil Siraj, who was given healing from COVID-19, delivered a message: firstly, you have to make physical efforts by following the doctor's instructions and directions, and secondly, your inner attempt is to get closer to Allah SWT through compulsory worship and practices (NUOnline, 2020).

Meanwhile, as a COVID-19 survivor, Aa Gym also conveyed his da'wa message through the @aagym Instagram account that the primary medicine for COVID-19 is to focus on remembering Allah by perfecting endeavors. There is no point in panic, confusion, and anxiety. We must be patient with Allah's destiny (Gymnastiar, 2020).

In addition, there are many debates about COVID-19 from controversial Islamic public figures. They consider the Coronavirus as punishment, the plague as a catastrophe, death as destiny, and COVID-19 as a political conspiracy and a weapon. The differences in the views of Islamic leaders influencing people's opinions, attitudes, and behavior towards the covid-19 pandemic. It is because some adhere to views of conservative, moderate, and progressive community groups. The Conservative community says a pandemic is the destiny of Allah. Humans can only surrender and repent by asking forgiveness to be saved from the pandemic. Moderates view this pandemic as natural law and part of a form of Allah's intervention so that humans must minimize its harmful effects. Meanwhile, progressive communities view the pandemic as originating from nature and as an effort to maintain the balance of life(Suherdiana et al., 2020).

This article looks at how Gus Mus (Ahmad Mustofa Bisri) conveyed the da'wa message as chair of the Raudlatut Thalibin Islamic Boarding School, Rembang, Central Java, and PBNU's Rais Syuriah during the pandemic on his social media. The da'wa message focus on Gus Mus's responses on social media to the COVID-19 pandemic. Gus Mus has three social media accounts; he managed them privately, a) Facebook account simbah. kakung, b) Instagram account @s.kakung, and c) Twitter account @gusmusgusmu. In this article, we only analyze his Instagram account @s.kakung. At the same time, Facebook and Twitter have synchronized with his Instagram account to be similar in content.

Gus Mus' Instagram with the account name @s.kakung was first active on December 30, 2015. In February 2021, the followers reach up to 521,442 , with 540 posts (Bisri, 2021). Using Instagram analytics recorded an average conversation of $6.02 \%$, the average favorite upload was $5.04 \%$, and the average comment was $0.08 \%$ (Analisa.io, 2021).

Article about Gus Mus' da'wa messages during the pandemic previously discussed the preaching of Nahdlatul Ulama da'wa in preventing COVID-19 from YouTube (Lukman Hakim \& Ali Aziz, 2020). The difference with this article is that it discusses Gus Mus' da'wa messages explicitly on Instagram.

The purpose of this paper is to find out Gus Mus's contribution as an Islamic public figure in responding to the COVID-19 pandemic by looking at the theme of da'wa 
messages and strategies for delivering da'wa messages uploaded to Instagram account @s.kakung.

\section{Method}

This research using the descriptive qualitative method with data analysis using qualitative content analysis techniques and collecting data through media observation and documentation. Qualitative content analysis works in data collection, data coding, data analysis, and data interpretation (Kriyantono, 2014; Nasrullah, 2014). Data collected from Instagram @s.kakung from March 16, 2020, to March 29, 2021. There was 150 uploaded content in that period, but the author only took 50 Instagram content that implied da'wa messages related to COVID-19.

The second step is data coding by creating a table/categorization of 50 content. The third stage is data analysis by linking the data findings with a theoretical study of $d a^{\prime} w a$ messages consisting of faith, Sharia, and morals (Aziz, 2009; Ilaihi, 2010). The data obtained were analyzed using da'wa messages in informative messages, persuasive messages, and informational messages (Suherdiana et al., 2020). The last is data interpretation.

\section{Result and Discussion}

\section{Instagram as a Communication Media during the COVID-19 Pandemic}

During the pandemic, Instagram was the third rank as the social media platform most used by Indonesians after YouTube and WhatsApp (Kompas.com, 2021). Instagram has a two-way communication pattern between users and followers in real-time. Instagram has information-sharing features in filterable photos and stories, comment fields, like buttons, hashtags to make it easier to find themes and live broadcasts. (Instagram, 2021).

Instagram's advantage over other social media applications lies in visual content. During the COVID-19 pandemic in Indonesia, Instagram uses for campaigning and socializing health protocols by the government through the Ministry of Health (Nasution, 2020), Ministry of Communication and Informatics (Hani\&Oktavianti,2021), Regional Heads (Anggraeni \& Soemantri, 2020). It is used as a communication medium from the online community kawalcovid19. id (Damayanti, 2020) to respond religious information during the pandemic (Agusta, 2020).

Instagram can also use to distribute da'wa messages. $D a$ 'wa messages consisting of faith, Sharia, and morals require media to amplify or disseminate da'wa to a broad audience (Ilaihi, 2010). During the pandemic, the community's problems included health contact with Muslim worship procedures, understanding viruses and pandemics from the perspective of aqidah, aspects of adhering to health protocols as muamalah, and morals with others to the law of vaccines. Muslims need Influencers whose ideas, words, and content can positively influence society (Afifi et al., 2019). Instagram has a comment feature as a form of direct communication (Alam, 2020). For the Muslim community, ustadz, $d a^{\prime} i$, kiai, and Gus were the influencers they trusted. (Briandana et al., 2020).

\section{Da'wa messages on the Instagram account @s.kakung}

President Joko Widodo first announced the case of COVID-19 in Indonesia on March 2 , 2020. In the following days, coronavirus infection continued to increase. On March 
12, 2020, the World Health Organization (WHO) announced the status of Coronavirus as a pandemic. The Indonesian government implements policy "Learning from Home, Working from Home and Worshiping from Home". It starts on March 16, 2020, to cut of the COVID-19 chain in Indonesia. The author's observations show that Gus Mus participated in responding to this situation by uploading the pandemic condition through his Instagram account. Gus Mus's first post on March 16, 2020, as seen in Figure 1.

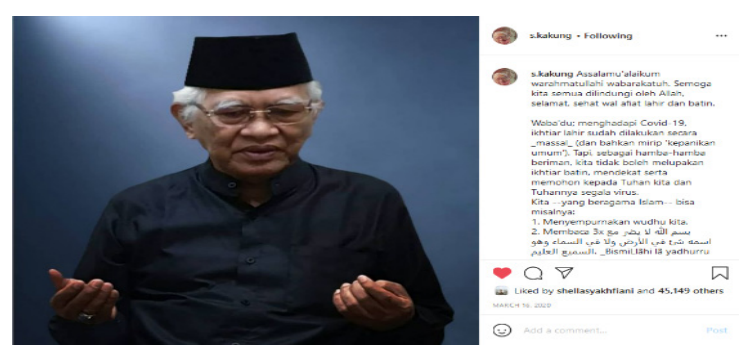

Figure 1. The first post related to Covid-19 publishes on March 16, 2020. Sources https:// www.instagram.com/p/B9xw9kkBle8/

Gus Mus prayed for the Indonesian people would always be protected by Allah, be given physical and mental health, and would not forget the inner efforts as written in his Instagram account:

"(1) Perfecting ablution, (2) Reading $3 x$ "Bismillahi la yadhurru ma'asmihi syaiun fil ardhi wala fissamai wahuas samii'ul 'aliim", after Fajr and Maghrib; and when going out of the house., (3) Wirid Asma prayer. (4) Read the prayer of the Prophet SAW that you like/memorize (5) Pray: "Allahumma inna nas'aluka al-'afwa wal-afiata wal mu'afata ad-daimata fiddiini waddunya wal akhirah Allah "yes Greetings, ya Hafiizh, and ya Mani'u ya Dharru", each read at least 20 times after each."

Within one week, Gus Mus posted successively about COVID-19. Gus Mus' posts include; regarding the invitation to remember Allah SWT when you have to stay at home during a pandemic, both in the form of narration and poetry. Gus Mus also appreciates the \#SalingJaga Movement initiated by Alissa Wahid (Gusdurian Activist) in collecting aid to help vulnerable communities affected by COVID-19, as shown in Figure 2.

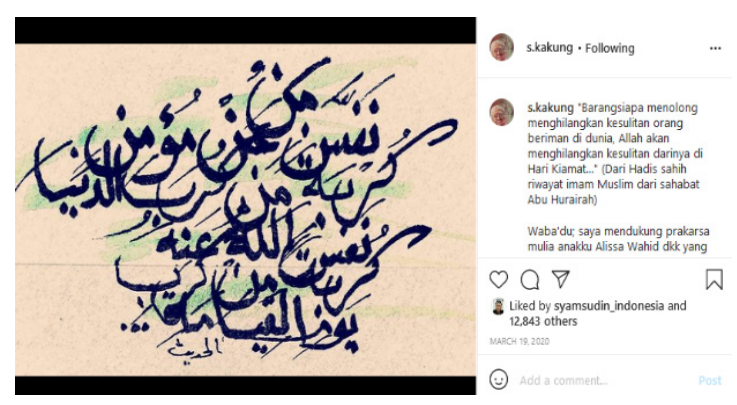

Figure 2. Excerpt of Hadits Sahih Muslim about mutual help, uploaded on 19 Maret 2020. Source: https://www.instagram.com/p/B958j4khUsY/

Gus Mus also advised following the government's directions for \#DirumahAja and \#JagaJarak, and he uploaded it on March 21, 2020.

"Assalamu'alaikum warahmatullahi wabarakatuh. Dear Muslim, hafizhakumuLlãh. As is well known, we, all Indonesians in particular and citizens of the world are currently experiencing a disaster with the emergence of the Corona Virus (COVID-19 -19). It is as if Allah sent this virus to remind us. We have been forgetting - made forgetful by the world charm and fanaticism of the group - are reminded of His words "Yã ayyuhánnãs Inna khlaqNãkum min dzakarin wä untsä ...." (Q. 49: 13). He created from male and female, and He made tribes and nations know each other-caring for each other.

The Apostle reminds us that we are all from one Father. "Kullukum min Adam wä Adam min turãb." With this stern warning - in which we social creatures are forced to be alone and maintain a distance from each other - it is hoped that we will become aware of our brotherhood as humans. And then start by working together for the common good, facing the plague that threatens us all. Each according to his station and ability. All matters left to the experts: Health affairs to health experts; religious experiences to religious experts. The gov- 
ernment regulates according to its authorities and responsibilities.

We, the layman, help by following the directions of the competent parties.

Waba'du; besides following directions, temporarily at home, maintaining cleanliness, maintaining distance, etc. We, especially the Muslims, can help with mental endeavors, namely increasing istighfãr (astaghfiruLlãhal 'Azhiim) and the Prophet's prayers (which we like/memorize). Gratitude also read the prayer "Hizib Bahr" of Sheikh Abul Hasan Asy-Syadzili. (The text see my next post). May Allah protect us all."

In April 2020, Gus Mus's posts in the form of the Hizib Autad Prayer of Syeikh Abdul Qadir Al-Jailani and Syeikh Jalaluddin As-Suyuthi fortress the corona outbreak.

"Prayers and Hezib are only for my interested brothers. I uploaded Sheikh Abdul Qadir Al-Jailani's Hizib Autad. I added a diploma from Sheikh Jalaluddin As-Suyuthi to fortify myself from the plague. This: "Salamun qaulan min Rabbin Rahiim." Read it 280x. May be useful." (source: https://www.instagram.com/p/B9_Vdedh-X4/)
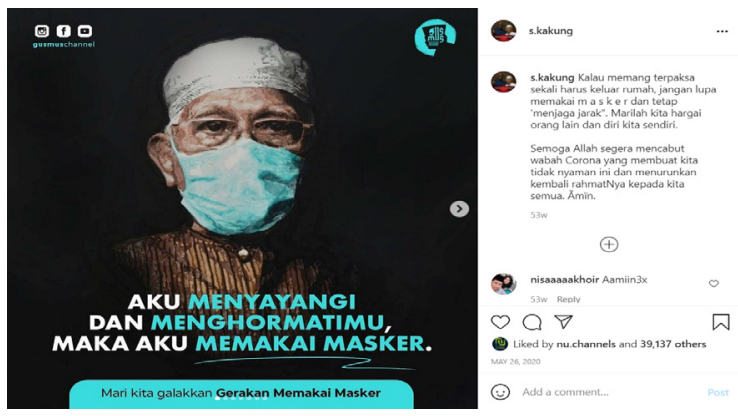

Figure 3. Gus Mus is always wearing a masker, uploaded on May 26, 2020. Source https://www.

instagram.com/p/CAo6AqNBC8r/.

From mid-April 2020 to March 2021, Gus Mus also wears a mask in every upload during sports, gatherings with his family, and grandchildren.

When relatives or guests visit his house, of the 50 posts that Gus Mus uploaded during the pandemic, there are 35 photos wearing masks, as shown in Figure 3.
Gus Mus positioned himself as a model in the mask campaign. Gus Mus posts activities with always wears a mask, as shown in Figures 4 to 6. We can saw that Gus Mus tries to convey non-verbal messages to his Instagram followers and the broader community to wears a mask in every activity.

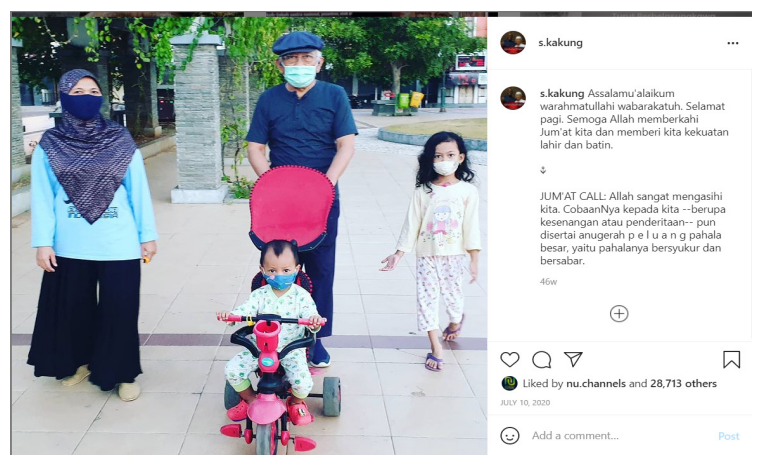

Figure 4. Gus Mus walks with his family always wears masks, post on July 10, 2020. Source https://www.instagram.com/p/CCcR3IYheuZ/

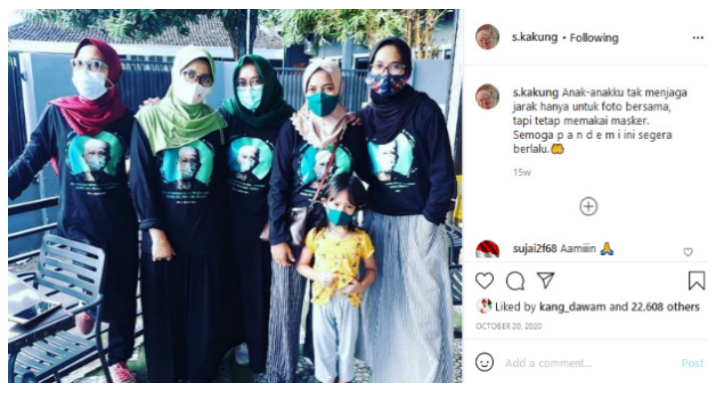

Figure 5. Family shot always uses masks, post on October 20, 2020, source https://www. instagram.com/p/CGi--WLhjRO/

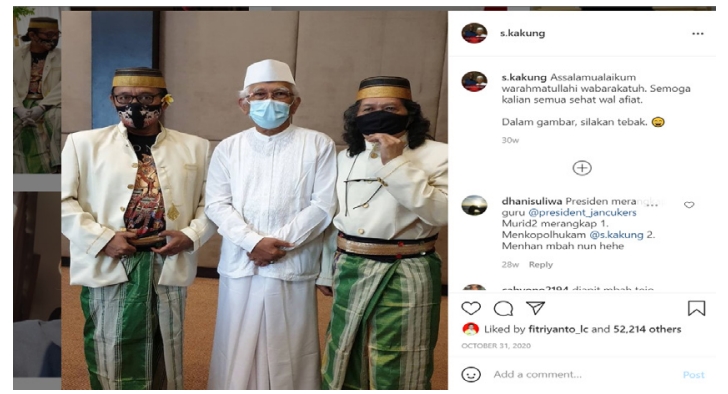

Figure 6. Gus Mus and colleagues on a mask, post on October 31, 2020. Source https://www. instagram.com/p/CG_0ej4BYyv/ 
Instagram @s.kakung account also said condolence when 100 doctors and health workers died. They died due to being infected with COVID-19 through a video upload with a duration of 08.03 minutes on September 3, 2020. The following is the caption.

Inna lillahi wainna ilaihi raji'un.

We express our deep condolences for the deaths of dozens of medical personnel and doctors who are fighting on the front lines against the Corona outbreak. May their spirits be placed in a proper place by His side according to their merits and struggles. May the families gave courage and patience. May the doctors and medical personnel still struggling on the front lines against this plague be guarded by Allah and given additional inner and outer strength. May Allah immediately raise and dispel this plague from the face of the earth. Âmïn.

The video uploaded by @s.kakung also expressed his regret at a public official who said that the health worker mortality rate was due to a lack of discipline on health protocols. Gus Mus urged public officials to think about his every statement because it could hurt health workers. Health workers are the frontline in overcoming this pandemic, are unlikely to act disciplinarily. Besides that, health workers remind the public to be disciplined and obey health protocols for the first time.

In his video, Gus Mus also appealed to all leaders, both the president and the ranks of public officials below it, to be more careful and rethink every statement addressed to the public. Gus Mus urged every report to think about whether it will hurt people, hurt other people's feelings, or not. The condition of facing a common enemy (COVID-19) requires a pious and wise leader.

The uploading the @s.kakung account about condolences to health workers, online media reported it (Akurat. co, 2020; Bisnis.com, 2020; Detik.com, 2020; Suara.com, 2020), in addition to uploading @s.kakung, it was also re-uploaded on the @ GusMusChannel Facebook in the opportunity to meet face to face with the administrators of the Indonesian Doctors Association (IDI) via online. Gus Mus supports IDI, who continues to fight as the vanguard of handling COVID-19 in Indonesia, and asks the government and the public to follow IDI's recommendations and instructions.

Gus Mus gets his first chance of being vaccinated on March 1, 2021, and the second vaccination on March 29, 2021. During his first vaccination in Gus Mus's post, he received comments in prayers from several public figures such as Najwa Shihab, Nadirsyah Hosen, Lukman Hakim Saifuddin, and Hanif Dhakiri. Then Gus Mus made a second vaccination post by claiming that he still adhered to the Health protocol even after vaccination.

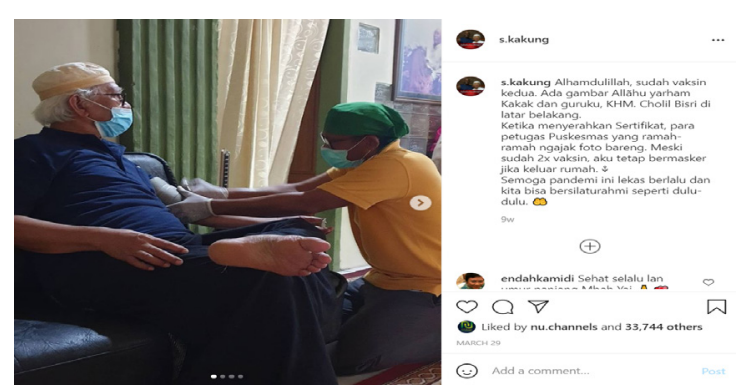

Figure 7. Gus Mus being vaccinated by a health worker, posts on March 29, 2021. Source https:// www.instagram.com/p/CM_N4G3BMlQ/

Gus Mus's Da'wa content at Instagram classifies into three categories, as shown in Table 1. 
Table 1. Da'wa content categorization of the @s.kakung account for March 16, 2020 - March 29, 2021.

\begin{tabular}{|c|c|c|}
\hline Theme & Sub Theme & Messages \\
\hline $\begin{array}{l}\text { Aqidah } \\
\text { (Faith) }\end{array}$ & $\begin{array}{l}\text { - Faith in Allah } \\
\text { - Faith in qada } \\
\text { and qadar }\end{array}$ & $\begin{array}{l}\text { - "In the face of COVID-19 -19, birth efforts have been carried } \\
\text { out masse (and even resemble 'general panic'). But, as faith- } \\
\text { ful servants, we must not forget our inner efforts, approach } \\
\text { and ask our Lord and God of all viruses." } \\
\text { - "We, who have been cultivating ourselves and uniting the } \\
\text { world to a distance from the Creator, have we learned a les- } \\
\text { son from the presence of His tiny creature called the Corona } \\
\text { Virus, which is making mass panic right now?" } \\
\text { - "This Corona pandemic should undermine our pride and } \\
\text { remind us that we are all human, our fellow children, and } \\
\text { grandchildren of Adam. (Q. 49: 13)" } \\
\text { - "Let's pray for Allah's grace. We hope the Corona ordeal will } \\
\text { immediately disappear. We can stay in touch again physically. } \\
\text { We strive for goodness and improvement for all." } \\
\text { - "Obeying Allah's commandments to work for the common } \\
\text { good, I wear and invite you to wear a mask." } \\
\text { "If we perceive pandemics and calamities as trials or warn- } \\
\text { ings from Allah, then we must not forget that these trials/ } \\
\text { reprimands are for all of us." }\end{array}$ \\
\hline $\begin{array}{l}\text { Syariah } \\
\text { (Sharia) }\end{array}$ & $\begin{array}{l}\text { - Worship } \\
\text { (taharah, } \\
\text { fasting, zakat, } \\
\text { pilgrimage, } \\
\text { prayer) } \\
\text { - Muamalah } \\
\text { (civil law, } \\
\text { public law) }\end{array}$ & $\begin{array}{l}\text { - Appeals to complete ablution, pray, do wirid, read the Proph- } \\
\text { et's shalawat. } \\
\text { - Give Hizib autad practice. Pray for recovery for COVID-19 pa- } \\
\text { tients. }\end{array}$ \\
\hline $\begin{array}{l}\text { Akhlaq } \\
\text { (moral) }\end{array}$ & $\begin{array}{l}\text { - } \text { Morals to } \\
\text { Allah } \\
\text { - } \text { Morals to } \\
\text { creatures }\end{array}$ & $\begin{array}{l}\text { - "I support the noble initiative of my daughter, Alissa Wahid, } \\
\text { and friends who invite us to help ease the burden on our } \\
\text { brothers and sisters who are affected by the Coronavirus to- } \\
\text { day. May Allah be happy and help us all." } \\
\text { - "And then start by working together for the common good, } \\
\text { facing the plague that threatens us all. Each according to our } \\
\text { station and ability. All matters left to the experts: Health af- } \\
\text { fairs to health experts; religious experiences to religious ex- } \\
\text { perts. The government regulates according to its authorities } \\
\text { and responsibilities. } \\
\text { "We, the layman, help by following the directions of the com- } \\
\text { petent parties." } \\
\text { "Inna lillahi wainna ilaihi raji'un. We express our deep con- } \\
\text { dolences for the deaths of dozens of medical personnel and } \\
\text { doctors who are fighting on the front lines against the Corona } \\
\text { outbreak." }\end{array}$ \\
\hline
\end{tabular}




\begin{tabular}{ll}
\hline Theme Sub Theme $\quad$ Messages \\
\hline - "We hope that all of you who are \#dirumahaja will always re- \\
ceive protection from Allah and are in good health. For those \\
struggling to help themselves, especially those helping oth- \\
ers deal with the Corona outbreak, we pray that Allah will \\
always be blessed and blessed with inner and outer strength. \\
- Hopefully, this plague will disappear soon. Amïn." \\
"If you have to leave the house, don't forget to wear a mask \\
and keep your 'distance'. Let us respect other people and our- \\
- "Welves" \\
"Wands during this pandemic is part of our expressions of re- \\
- "Mect and affection for others." \\
- still wear masks. Hopefully, this pandemic will pass soon". \\
"Do not forget to make efforts for our benefit together by \\
wearing masks; keep the distance; diligently wash hands, \\
and avoid the crowd". \\
Even though I have got a vaccine twice, I still have a mask \\
when I leave the house. Hopefully, this pandemic will pass \\
quickly, and we can stay in touch like we used to
\end{tabular}

Da'wa messages in the da'wa process consist of faith, syariah, and ahlaq. The article of this creed is to believe in Allah, angels, AlQur'an, apostles, and qada and qadar. Syariah themes include specific worship such as taharah, prayer, fasting, zakat, and hajj), and muamalah, such as civil law and public law. At the same time, the theme of morals includes morals to Allah and morals to humans (Aziz, 2009). The tendency of Gus Mus' da'wa messages on the @s.kakung account during the pandemic was also about COVID-19 in the themes of faith, syariah, and morals.

Gus Mus uploaded to @s.kakung account in a pandemic condition that we must never forget Allah. COVID-19 teaches humans to undermine human pride and reminds all humans, as Adam's grandchildren, to unite in facing the pandemic, obeying Allah's orders to comply with health protocols. Da'wa messages on the syariah are making inner efforts. We can do it by praying, reading wirid, shalawat to the Prophet, and the practice of Hizib autad.

Da'wa messages with the morality theme uploaded by @s.kakung are supporting the movement to help people. Especially people who are vulnerable to being economically affected by COVID-19. We should obey health experts and the government, express gratitude for the struggles of doctors and health workers who are fighting at the forefront. We should say condolences to doctors and health workers who died on duty. We must constantly remind people to always obey health protocols by wearing masks, maintaining distance, washing hands, avoiding crowds, and implementing health protocols when Gus Mus is with his family.

Meanwhile, Efendi's strategy of delivering da'wa messages (Suherdiana et al., 2020) can follow three types of messages: informative, persuasive, and instructive. 
First, informative messages, namely da'wa messages delivered by preachers containing information to add insight to mad'u. Second, persuasive messages, namely the message of da'wa conveyed by preachers to influence mad'u to follow what the preachers say without coercion. Third, the instructive message, namely the message of da'wa from the da'i, contains the command for mad'u to do something.

Delivering Gus Mus' da'wa messages in the Instagram @ s.kakung account uses more persuasive messages and informative messages. This compelling message is in Gus Mus' invitation to remember Allah in a pandemic condition. He invites us to follow the competent authorities in this case, doctors and health workers in handling COVID-19, invites cooperation to help communities affected by the pandemic, asks to always obey health protocols such as masking, following vaccinations. The persuasive message was in Gus Mus's 50 posts from March 16, 2020, to March 29, 2021. In addition, there were 35 posts of Gus Mus wearing a mask and constantly reminding in the description of his Instagram upload (caption) to continue wearing a mask.

The second strategy of delivering Gus Mus' da'wa messages is informative messages. We can find it in Gus Mus' post, which provides prayer readings and good deeds of wirid, shalawat and Hizib autad.

\section{Conclusion}

Through his Instagram, Gus Mus has responded to the COVID-19 pandemic since Indonesia. There are three pandemic periods in Indonesia: the initial pandemic period, the new-normal period, and the vaccination period. From March 16, 2020, to March 29, 2021, Gus Mus has posted 50 content with da'wa messages on the theme of faith, syariah, and morals. The strategy of delivering Gus Mus' da'wa messages during the pandemic was persuasive and informative communication. Gus Mus has acted as a motivator who continually prays for his followers and the more comprehensive community health during the pandemic. Gus Mus is also a role model in implementing health protocols, highly supports and appreciates doctors and health workers' work, follows vaccinations, and adheres to post-vaccination health protocols.

\section{References}

Afifi, T. D., Merrill, A., Davis, S., Denes, A., \& Coveleski, S. (2019). The Impact of a Need for Closure and Support Quality on Verbal and Cognitive Brooding. Communication Research, 46(6), 757-784. https://doi. org/10.1177/0093650216644018

Agusta, A. S. (2020). Fresh Informasi Keagamaan Melalui Media Instagram Dalam Menanggapi Covid-19 Di Indonesia. Journal of Library, 11(2), 8899.

Akurat.co. (2020). Ungkapan Belasungkawa Gus Mus untuk 100 Dokter yang Meninggal karena Corona.

Alam, S. (2020). Peran Influencer Sebagai Komunikasi Persuasif Untuk Pencegahan COVID-19. 8(2), 136-148.

Analisa.io. (2021). Instagram Analytics. Analisa.Io.

Anggraeni, Y., \& Soemantri, Y. S. (2020). The Expressive Speech Act on Ridwan Kamil's Comments in Instagram Posting 
about First COVID-19 Case in Indonesia. Journal of English Education and Teaching (JEET), 4(3), 368-385.

Arrobi, M. Z., \& Nadzifah, A. (2020). Otoritas Agama di Era Korona: Dari Fragmentasi Ke Konvergensi? Maarif, 15(1), 197-215. https://doi.org/10.47651/mrf.v15i1.85

Aula, S. K. N.(2020). Peran Tokoh Agama Dalam Memutus Rantai Pandemi Covid-19 Di Media Online Indonesia. Living Islam: Journal of Islamic Discourses, 3(1), 125148.

Aziz, M. A. (2009). Ilmu Dakwah (2nd ed.). Kencana Prenadamedia.

Bisnis.com. (2020). Banyak Tenaga Medis Gugur Melawan Covid-19, Begini Pesan Gus Mus.

Bisri, A. M. (2021).Akun Instagram @s.kakung. Instagram.

Briandana, R., Doktoralina, C. M., Hassan, S. A., \& Hasan, W. N. W. (2020). Da'wah communication and social media: The interpretation of millennials in Southeast Asia. International Journal of Economics and Business Administration, 8(1), 216-226. https://doi.org/10.35808/ ijeba/543

Damayanti, A. (2020). Instagram sebagai Medium Komunikasi Risiko di Masa Pandemi COVID-19: Studi Netnografi terhadap Komunitas Online KawalCOVID19.id. Journal of Development Communication, 18(02), 176-193. https://doi. org/10.46937/18202032355

Detik.com. (2020). Doa dan Dukacita Gus MusBuya Syafii untuk Dokter yang Gugur Lawan Corona.

Fakhruroji, M. (2017). Dakwah di Era Media
Baru Teori dan Aktivisme Dakwah di Internet (1st ed.). Simbiosa Rekatama Media.

Gymnastiar, A. (2020). Akun Instagram @ aagym. Instagram.

Hakim, M. L., \& Aziz, M. A. (2020). Dakwah Da 'i Nahdlatul Ulama dalam Mencegah. 20(September), 200-219.

Hani, C., \& Oktavianti, R. (2021). Proses Organisasi Informasi COVID-19 Pada Media Sosial Instagram Kementerian Komunikasi dan Informatika Republik Indonesia. Koneksi, 5(1), 113. https:// doi.org/10.24912/kn.v5i1.10189

Hidayaturrahman, M., Husamah, H., Sudarman, S., Yanti, F., \& Kusumawati, I. R. (2021). Religious Behavior of Indonesian Muslims as Responses to the Covid-19 Pandemic. Al-Adabiya: Journal of Culture and Religosity, 16(1), 1-14. https://doi. org/10.37680/adabiya.v16i1.704

Hilmy, M., \& Niam, K. (2020). Winning The Battle of Authorities: The Muslim Disputes Over The COVID-19 Pandemic Plague in Contemporary Indonesia. Qudus International Journal of Islamic Studies (QIJIS), 8(2), 293-326. https:// doi.org/10.21043/qijis.v8i2.7670

Ilaihi, W. (2010). Komunikasi Dakwah. Remaja Rosdakarya.

Instagram. (2021). Instagram About Official Site.

Kompas.com. (2020). New Normal, Menag Terbitkan Aturan Rumah Ibadah Wajib Punya Surat Bebas Covid-19. Kompas. Com.

Kompas.com. (2021). Riset Ungkap Lebih dari Separuh Penduduk Indonesia "Melek" Media Sosial. 
Kriyantono, R. (2014). Teknis Praktis Riset Komunikasi (7th ed.). Kencana Prenadamedia.

Lukman Hakim, M., \& Ali Aziz, M. (2020). Dakwah Da'i Nahdlatul Ulama dalam Mencegah Penyebaran Covid-19. Anida (Aktualisasi Nuansa Ilmu Dakwah), 20(2), 200-220. https://doi.org/10.15575/ anida.v20i2.10820

Munir, M., Fauzi, M., \& Putra, R. A. (2020). Pesan-Pesan Dakwah Da'i Pada Khalayak (Analisis Konten Pada Ceramah Da'i tentang Covid-19 di Youtube). ATTABSYIR: Journal of Islamic Broadcasting and Communication, 7(1), 138-159. https://doi.org/10.21043/at-tabsyir. v7i1.7685

Nasrullah, R. (2014). Teori dan Riset Media Siber (Cybermedia) (1st ed.). Kencana Prenadamedia.

Nasrullah, R. (2016). Media Sosial : Perspektif Komunikasi, Budaya dan Sosioteknologi. Simbiosa Rekatama Media.

Nasution, F. I. (2020). Pengaruh Peringatan Kesehatan pada Akun Instagram @ Kemenkes_RI Terhadap Sikap Hidup Sehat Masyarakat (Studi pada Masyarakat Kecamatan Cicendo Kota Bandung dimoderasi oleh Tingkat Pengetahuan Covid-19).
NUOnline. (2020). Amalan Cepat Sembuh dari Covid-19 Menurut Kiai Said Aqil Siroj.

Pabbajah, M., Said, N. M., \& Pabbajah, M. T. H. (2020). Reauthorization of the Religious Leader Role in Countering Covid- 19: Perceptions and Responses of Muslim Societies on the Ulama's Policies. August. https://doi.org/10.6000/19294409.2020.09.25

Sofian, F. A. (2020). YouTubers creativity in creating public awareness of COVID-19 in Indonesia: A youtube content analysis. Proceedings of 2020 International Conference on Information Management and Technology, ICIMTech 2020, August, 881-886. https://doi.org/10.1109/ ICIMTech50083.2020.9211149

Suara.com. (2020). Gus Mus Peringatkan Pejabat yang Bilang Nakes Meninggal karena Tak Disiplin.

Suherdiana, D., Ridwan, A., \& Fatoni, U. (2020). Pesan Dakwah Ormas Islam Indonesia dalam Menghadapi Krisis Keagamaan Masa Pandemi Covid-19. Karya Tulis Ilmiah.

Tribunnews. (2021). MUI: Ada 200an Ulama yang Meninggal karena Terpapar Covid-19. 